\title{
ANALYSIS OF EPONYMS IN THE TERMINOLOGY OF DERMATOVENEROLOGY
}

${ }^{1}$ Nilufar Sadullaeva, ${ }^{2}$ Dilfuza Sapaeva

${ }^{1}$ National University of Uzbekistan, Tashkent, Uzbekistan. E-mail: nilufar_sadullaeva@mail.ru

${ }^{2}$ Urgench branch of Tashkent Medical Academy, Urgench, Uzbekistan. E-mail: dilfuza.sapayeva@bk.ru

\begin{abstract}
The article presents the results of a study devoted to such an aspect of terminological competence as eponyms. The paper provides a general description of eponyms in the anatomical terminology of English and Uzbek languages. Eponymic terms are an integral part of the medical terminology of different languages that form the scientific discourse. Eponyms as part of the language of science contribute to a deeper understanding of human activity and his culture. The sublanguage of medicine is the most important source of knowledge about those people who created this science, and the tendency in modern linguistics to study the human factor allows us to consider the terms-eponyms in the light of the cognitive approach.
\end{abstract}

Keywords:

competence, eponyms, medical eponymous terminology, skin diseases, sign, phenomenon.

Article Received: 18 October 2020, Revised: 3 November 2020, Accepted: 24 December 2020

\section{Introduction}

Issues related to strengthening human health, which is an invaluable asset of society, improving the quality of medical services in our country have always been in the focus of the head of our state. During his visits to the regions, President Shavkat Mirziyoyev visited a number of social facilities, including rural medical centers, multidisciplinary clinics, and communicated directly with doctors and patients, which allows to effectively address many issues on the ground.

One of the most productive areas of the lexicon of modern medicine is the use of eponyms. Eponyms are terminological phrases in which a proper name acts as the first component. R. Nestmann notes that the reason for the emergence of eponyms is the need to designate newly appeared phenomena. These terms play an important role in naming new phenomena or discoveries in the field of medicine in connection with the established international tradition to name a particular discovery or invention by the name of the scientist who made this discovery or invention. Today it is difficult to find a field of medicine where eponyms are not used to one degree or another.
Along with the classical eponymous terms that came into use in the 16th-19th centuries, new terms constantly appear, reflecting both the stages of development of new branches of medical science, and the priority of one or another scientist or country in the discovery of new facts.

Today it is difficult to imagine the study of the evolution of clinical thinking, diagnosis, history and development of the clinic, medicine in general without knowledge of clinical terminological eponymy.

The problem of eponymy is the subject of many works by both linguists and representatives of various fields of knowledge. When conducting the research, we proceeded from the fact that an eponym (from the Greek eponymos - "giving his name"ed) means the name of a structure, concept, method named after the person who first discovered, discovered or described it. In professional medical terminology, terms containing proper names have become widespread. In the literature, such terms are called simply "eponyms", "eponymous terms", "eponymous terms". Eponymous terms reflect the evolution of medical knowledge and constitute a significant part of medical terminology. The word "eponym" itself is very rare, it is absent in the 
main encyclopedias and reference books, it can be found only in orthoepic and spelling dictionaries.

The subject of our work is the eponymous terms recorded in lexicographic sources, their use and features of functioning in different subsystems of medical terminology.

The study of the most common medical eponyms in English and Uzbek, based on the analysis of proper names, with the participation of which these terms were formed, lexical-semantic and derivational analysis of modern medical terminology, identification of quantitative and qualitative characteristics of eponymous terms, as well as an analysis of the main disadvantages, advantages and possibilities of eponymous terminology. The research used terminological dictionaries, medical documents, scientific publications, as well as scientific literature in the field of anatomy and practical medicine.

The study showed that the terminology fund of modern medical science contains a significant amount of eponymous terminology. Analysis of the historical aspect of the formation of eponyms has shown that the process of eponymization began in medicine in the middle of the last century with the naming of diseases by proper names in the field of neurology. In the 20th century, this process covered all areas of medicine. According to our data, the number of eponymous terms in the studied terminological systems is approximately eight thousand terms (this is a processed and systematized terminological fund, the total number of eponymous terms can be two to three times higher) . Share of eponymous terms in basic medical terminology is $10-12 \%$. The names of over 6 thousand doctors and scientists who represent more than 60 countries of the world are immortalized in eponymous terminology.

As E.V.Bekisheva points out, "despite the proposal of D.S.Lotte limit the use of eponymous terms, they have become widespread in various fields of science and technology and have an unlimited prospect of replenishment. This is explained, first of all, by the desire to immortalize the name of the scientist for future generations, as well as by insufficient attention of specialists to the process of term creation".

We do not entirely agree with the author of this statement: scientific term creation should also take into account the realities of scientific professional communication, in which eponimization, on the one hand, is aimed at verbal consolidation of the achievements of a certain scientific school, and on the other, it reflects the anthropocentric essence of language and human cognitive activity.

\section{Research Methodology}

Eponyms in medical terminology have been described in several scientific works, the authors of which give different classifications of these eponyms. The analysis of 6700 eponymous terms recorded in the "Anglo-Russian Medical Dictionary of Eponymous Terms" The latter include: two-component terminological combinations, consisting of a proper name and a common noun, which constitutes the thematic and structural core of the term. As the most frequent nuclear components, words from medical or general scientific vocabulary with a generalizing meaning were recorded, for example: disease, symptom, syndrome, fracture, dislocation, law, reaction, cells, operation, method, phenomenon, reflex, etc.

\section{Analysis and results}

As N.A.Pushkin, on the material of the English language, several names can be distinguished, including eponyms, which, as can be seen from the examples, also have Russian equivalents known to domestic medical specialists.

- disease (Shamberg's disease-Shamberg kasalligi )

- syndrome (Setton syndrome-Setton sindromi)

- anatomical units of the organs (Langerhans cells-Langergans hujayralari)

- medical theories (Flecherism Flecherizm) 
- research and treatment methods (Kyobner isomorphic reactionKyobner izomorf reaksiyasi )

- medicines (Salk and Sabin vaccine Solk va Sabina vaksinasi)

- medical instruments (Wood`s lampVud lampasi)

- disease detection tests (Balser testBalzer sinamasi)

As M.V.Vasin, eponyms can be divided according to the method of formation into several models.

- noun + preposition + proper noun (ampulla of Vater < Abraham Vater; pouch of Douglas < James Douglas)

- proper noun, transforming into an adjective (Gasserian ganglion < Johann Gasser; Haversian canal < Clopton Havers)

- proper noun in the possessive case + noun (Reuter`s Syndrome, Gugereau- Blum`s syndrome )

Eponymous terms can be found in many other languages (for example, in German, French), this, first of all, speaks of the globalization of science.

Also, the proper name in the structure of the eponym term makes it the keeper of culture and history, as N.A. Berdyaev, "so that the past continues in the future, so that we are not allowed to become impoverished with the great riches of the past".

The absence of eponymous terms in bilingual medical terminological dictionaries and thesauri significantly complicates the use of medical literature in foreign languages, complicates the teaching of students and leads to translation distortions. In this regard, in the following chapters, we analyzed modern bilingual English-Uzbek medical reference books for the presence of eponyms in them.

We have developed our own classification of eponymous terms based on dividing proper names into several groups, taking into account their origin. The source of information was scientific publications in English and Russian and bilingual medical dictionaries, which are noted in the bibliographic list. About 600 eponymous terms in English and Russian were found by the method of continuous sampling from factual material.

The first group includes eponyms based on personal names. These terms designate various symptoms, syndromes and diseases in which the names of the medical scientists who first described them or who first applied this method of treatment are captured:

- Melkersson-Rosenthal syndrome (uzb. Melkelsson Rozental sindromi) first described by Miescher in 1945, is a rare inflammatory disorder of unknown etiology characterized by recurrent swelling of the labial tissues.

- Quincke's edema (uzb. Kvinke shishi) also known as angioneurotic uvular edema, was named after Heinrich Quincke, a professor of internal medicine during the latter half of the $19^{\text {th }}$ century.

- Duhring-Brocq disease (uzb. Dyuringning gipetiform dermatiti ) was described and named in 1884 by Dr. Louis Duhring at the University of Pennsylvania.

- Prurigo nodularis of Hyde (uzb. Gaydning tugunli qichimasi ) first described In 1909, Hyde and Montgomery as a prurigo nodularis.

According to our data, this type of eponyms is the most common in the medical terminology of various languages, and make up about $80 \%$ of our sample. In the next group we include eponyms based on geographical names (toponyms).

Toponyms appear in the language of medicine as occasional names at the first stage of cognition, when the etiological and pathogenetic signs of the disease are unknown. The emergence of toponyms is a sociolinguistic problem in terminology, since an eponymous name is often created for the first time in mass media texts when describing epidemics of unknown etiology that have flared up anywhere in the world. The highest percentage of toponymic terms was recorded by 
us in the nomenclature of infectious diseases and is $10 \%$ of the sample:

- the first patients infected with Lyme disease were identified in 1975 in the American town of Lyme, etc.);

- Spanish fluis one of the forms of influenza that claimed thousands of lives in Europe at the beginning XX century.

In medical classifications, there are whole nests of toponymic terms, in which the geographical name indicates the type of disease or its manifestation, for example: blastomycosis (Brazilian blastomycosis), European (European blastomycosis), North American ( English North America blastomycosis), South American (English South America blastomycosis). Toponymic terms are not very informative, since their structure does not reflect the main features of a medical concept. Since, as mentioned above, the term-toponym is created by the author at the first stage of scientific knowledge, therefore, visual and superficial signs of the phenomenon are laid in the basis of the nomination. As knowledge of the etiology and pathogenesis of the disease deepens, more informative synonyms appear.

Comparative analysis of the use of eponymous terms in scientific dermatovenerological discourse in English and Uzbek (using the example of the literature under study) showed that descriptive terms of certain phenomena are more often found in dermatovenerological literature in English than in terminology in Uzbek, where, when describing eponyms are preferred to the same realities. Table 1 presents the main features of the use of eponyms and terminological correspondences established from dictionaries and medical scientific articles.

Table 1 Features of the use of eponyms and descriptive terms in dermatovenerological terminology

\begin{tabular}{|c|c|}
\hline Terms in English & Corresponding terms in Uzbek \\
\hline Quincke's edema & Kvinke shishi \\
\hline Setton syndrome & Setton sindromi \\
\hline Kebner phenomenon & Kebner fenomeni \\
\hline Wood`s lamp & Vud lampasi \\
\hline Balzer`s test & Balzer sinamasi \\
\hline Beacon disease & Mayokki kasalligi \\
\hline Ruiter allergic arteriolitis & Ruiter allergik arterioliti \\
\hline Bazen`s indurative erythema & Bazen indurativ eritemasi \\
\hline Becker`s nevus & Bekker xoli \\
\hline
\end{tabular}

The results of our research and analysis with the search for equivalents are given below in alphabetical order (Uzbek alphabet), in a pair the English equivalent is given, which is well established in the world scientific literature. For some (somewhat controversial) points, detailed explanations are given.

Graafov pufakchasi - antral follicle. In this example, the eponym has not survived in the English-language literature at all, and the stage of development of the ovum has a biological name antral follicle.
Shmorlya churrasi - Schmorl's nodes. The term "Schmorl's node" is also often found in the Russian-language scientific literature. They were originally named by the German scientist Christian Schmorl, who described them, SchmorlKnötchen, which literally means "tuguncha". By its origin, this X-ray phenomenon is not a true hernia.

Liddl sinamasi- dexamethasone suppression test. The specific method for diagnosing Itsenko-Cushing's syndrome using a test with dexamethasone according to the Liddle 
method is not mentioned in the English-language scientific literature and is simply designated as "dexamethasone suppression test".

Kraylya testi - prednisolone therapy. Such a specific method of "ex juvantibus" treatment as the Kraille test, based on an attempt to remove inflammation with the help of "glucocorticosteroids" (including with the help of prednisone), has acquired a name in the Englishlanguage literature not by its eponym, but by the essence of the method itself.

Based on the data studied and our own observations of the peculiarities of eponymous terms, it can be argued that all English-language eponymous terms can be divided into 5 groups, according to the method of their formation.

The most common way is to add an apostrophe 's to proper names, for example, Hodgkin's disease - chronic malignant lymphomatosis. In 1832 T. Hodgkin described seven patients in whom there was an increase in lymph nodes and spleen, general exhaustion and loss of strength. In all cases, the disease was fatal. 23 years later, S. Wilkes studied the cases described by Hodgkin in detail, added 11 of his own observations to them and called this condition Hodgkin's disease.

The second most frequent way of forming medical eponymous terms in English is to use a proper name without any changes. Jacquet dermatitis-it is another name for erosive from of irritant napkin dermatitis. The first true description of diaper dermatitis was made by Jacquet in 1905.

The third eponym model can be described as $\mathrm{N}+$ of + PN ( $\mathrm{N}$ - noun; $\mathrm{PN}$ - proper noun), for example: Erythema induratum of Bazin - in 1861, Bazin gave the name erythema induratum to a nodular eruption that occurred on the lower legs of young women with tuberculosis. Erythema induratum/nodular vasculitis complex is classified into 2 variants: erythema induratum of Bazin type and nodular vasculitis or erythema induratum of Whitfield type. The Bazin type is related with tuberculous origin, but Whitfield type is not.
The fourth way is to use a proper name in situations when it appears not as a dependent word, but as the main element, for example, Sabouraud agar - it is a type of agar containing peptones. It is used to cultivate dermatophytes and other types of fungi. It was created by, and is named after, Raymond Sabouraud in 1892.

In the fifth group we include the few eponyms that have passed from a proper name to another part of speech.

The use of eponyms in medical communication is likely to create confusion and ambiguity for many other reasons. One of these is the fact that since a physician may have described more than one disease, there are eponyms carrying the same name but referring to different diseases. The English physician Thomas Addison, for example, has given his name to several diseases or disorders, such as, for example, Addison's anaemia, Addison's crisis, and Addison's disease. There are also cases of eponyms containing the same name which, however, refers to different people - and to different conditions as well - as happens for Smith's disease (Carl), Smith's operation (Henry), Smith's fracture (Robert William). Even worse is the case of eponyms containing not only the same proper name referring once again to different people - but also the same headword.

Examples are Alexander's syndrome, where the proper name refers to two distinct people (Benjamin and William Stuart), or even the case of the four homonymous eponyms Pick's disease (Arnold, Friedel J., Ludwig, and Philipp J.).

\section{Conclusion}

Medical language is replete with eponyms. Although their use has often been criticized by many, no doubt extraordinary is their capability to encapsulate long and complex concepts very concisely. This is probably one of the main reasons why they continue to flourish in medical language. Both eponyms and equivalent descriptive terms can have positive and negative aspects. Eponyms can be tricky and confusing on 
a pragmatic level. They can be multiple, if they contain more than one name; homonymous, because headwords can be named after several people having the same last name; misspelled, because names may be difficult to pronounce and transcribe; inaccurate, as sometimes some of them are erroneously used as synonyms; obscure, as they are not descriptive (with the exception of 'hybrid' eponyms). Descriptive terms, on the other hand, give scientific information, and their use does not generally give rise to misunderstandings and semantic ambiguity. However, they can be inaccurate too, especially when they are not used in the meaning their surface form would suggest (e.g. the suffix -itis instead of -osis). Eponymous terms cannot be completely excluded from medical terminology. We suggest using eponymous terms only in cases where synonymous terms do not fully reflect the essence of the concept, and the definition of a concept using a verbose descriptive construction is not convenient. An important issue in general lexicography is the way of registration and processing of eponyms in the corpus of dictionaries of various types.

\section{References}

[1] Arnaudov G.D. Medical terminology in 5 languages. (Latinum, Russian, English, Francais, Deutsch)/ G.D.Arnaudov. -Sofia: 1979.-943 p.

[2] Моисеев М.В. Термины-топонимы в медицине (сравнительный анализ на материале английского, немецкого и русского языков) / М.В.Моисеев // Медицинская терминология и гуманитарные аспекты образования в медицинском ВУЗе: Тез. докл. Всрос. науч. конф,-Самара: СГМУ, 1998.-С. 135136.

[3] Кириллова Т.е. Пути формирования и лексикологические особенности английской терминологии подъязыка медицины (дерматология-венерология): Автореф. дис. ...канд. филол. наук: 10.02,04 /ПГПИИЯ.-Пятигорск, 1990.- 17 c.

[4] Sadullaeva N.A., Mamatova F.B. Classification of euphemism and its formation in the Uzbek language. Journal of critical reviews. Vol 7, Issue 4. 2020. Malaysia. ISSN 2394-5125

[5] http://www.jcreview.com/fulltext/1971584972123.pdf?1586606700

[6] Sadullaeva Sh.A., Arustamyan Y.Y., Sadullaeva N.A. Shifting the Assessment Paradigm from Knowledge to Skills: Implementation of New Appraisal Procedures in EFL Classes in Uzbekistan. International Journal of Innovative Technology and Exploring Engineering, 2019

[7] https://www.ijitee.org/wpcontent/uploads/papers/v9i1/A9179119119.p df

[8] Sapaeva D., Sadullaeva N.A. Features of Abbreviations used in Medical Terminology. Journal of critical reviews. Vol 7, Issue 5. 2020. Malaysia. ISSN 2394-5125

[9] http://www.jcreview.com/index.php?term=F eatures+of+Abbreviations+used+in+Medical +Terminology\&sarea 